\title{
STUDI BIOGRAFI KEHIDUPAN DAN PERTOBATAN PAULUS SEBAGAI MODEL PERTOBATAN PELAKU KRIMINALITAS SAAT INI
}

\author{
Fandri Watulingas*1 \\ ${ }^{1}$ Sekolah Tinggi Teeologi Indonesia Manado \\ fandrywatulingas@gmail.com
}

\section{BIOGRAPHY STUDY OF PAUL'S LIFE AND REPENTANCE AS A MODEL OF CURRENT CRIMINAL CONTENTS}

\begin{abstract}
The level of evil in this world, will not end until the second coming of the Lord Jesus. There are many levels of crime that occur in society ranging from fraud, robbery, rape and even murder, sometimes criminals think with the magnitude of the crime they have committed, Allah will not forgive their sins. The research method used is bibliography by taking every source that has a relationship with the biography and conversion of Paul and arranged based on the background of his life to his conversion. The purpose of this article is to find out 1). How do you study the biography of Paul's life? 2). Can Paul's repentance be a model of repentance for criminals today? The results of this study are 1). Paul was born in Tarshish Paul's parents were members of a Jewish group. Paul's achievement was to speak two languages, Aramaic and Greek. Paul as a member of the Sanhedrin hated Christians Paul's conversion occurred "on the way to Damascus to arrest Christians, he met Christ through a vision. 2). Paul gives an example to criminals that there is no sin that cannot be forgiven if they truly repent and believe in Jesus Christ.
\end{abstract}

\section{Keywords: Crime, Repentance, Paul}

\begin{abstract}
Abstrak: Tingkat kejahatan di dunia ini, tidak ada habisnya hingga kedatangan Tuhan Yesus pada kali yang kedua. Ada banyak tingkat kriminalitas yang terjadi di masyarakat mulai dari penipuan, perampokan, pemerkosaan bahkan sampai pada pembunuhan, terkadang pelaku kriminalitas berpikir dengan besarnya kejahatan yang mereka lakukan, Allah tidak akan mengampuni dosa mereka. Metode penelitian yang digunakan adalah bibliografi dengan mengambil setiap sumber yang ada hubunngan dengan biografi dan pertobatan Paulus dan disusun berdasarkan berdasarkan latar belakang kehidupan hingga pertobatannya. Tujuan dari artikel ini adalah untuk mengetahui 1). Bagaimanakah studi bibiografi kehidupan Paulus? 2). Apakah pertobatan paulus dapat menjadi model pertobatan pelaku kriminalitas saat ini? Hasil dari penelitian ini adalah 1). Paulus lahir di Tarsis Orang tua Paulus adalah anggota kelompok Yahudi. Prestasi yang ditempu Paulus yaitu berbicara dengan dua bahasa, Bahasa Aram dan Bahasa Yunani. Paulus sebagai anggota Sanhedrin sangat membenci orang Kristen Pertobatan Paulus terjadi "pada perjalan menuju ke Damsyik untuk menangkap orang-orang Kristen, ia berjumpa dengan Kristus melalui suatu penglihatan. 2). Paulus memberikan contoh pada pelaku kriminalitas bahwa tidak ada dosa yang tidak bisa diampuni apabila mereka sungguh-sungguh bertobat dan percaya kepada Yesus Kristus.
\end{abstract}

Kata-kata kunci: Kriminalitas, Pertobatan, Paulus 


\section{PENDAHULUAN}

Paulus seorang tokoh Alkitab yang luar biasa dipakai Tuhan. Sebelum Paulus bertobat, ia adalah seorang yang taat beragama dalam memegang teguh keyakinannya tentang Yudaisme dan menjadi penganiaya jemaat Tuhan oleh karena kepercayaanya kepada Allah monoteisme yaitu Allahnya Abraham, Ishak dan Yakup nenek moyang Israel. Bagi orang Yahudi, jika ada orang yang menyebut Nama Allah selain Allahnya Abraham, Ishak dan Yakup maka orang tersebut dianggap menghujat nama Allah dan harus dilontar dengan batu hingga mati.

Salah seorang yang dianggap menghujat nama Allah adalah Stefanus. Ia mati dengan cara dirajam dengan batu oleh karena mengakui Yesus Kristus sebabai Tuhan dan saat kematiannya Saulus hadir dan Ia setuju. Paulus saat perjalanan di Damsik untuk menangkap orang-orang percaya, ia mendapatkan pengalaman yang spektakuler karena memperoleh penyataan Yesus sendiri dan ada cahaya yang membuat Paulus reba dan menjadi buta dalam beberapa hari. Momentum tersebut membuat Paulus bertobat dan percaya kepada Yesusu Kristus. Paulus mengakui bahwa, ia adalah orang yang paling bedosa dibandingkan yang lain dan dengan demikian ia menjadi contoh bagi para petobat baru.

Perkembangan tingkat kriminalitas di kota-kota besar cenderung meningkat. Misalnya di provensi Banten "Kriminalitas di wilayah Provinsi Banten mengalami peningkatan cukup signifikan atau mencapai 68 persen sepanjang tahun 2014 dibandingkan tahun 2013. Peningkatan kriminalitas konvensional dan transnasional di wilayah hukum Polda Banten dibandingkan tahun lalu merujuk data, tindak kriminalitas tahun 2013 sebanyak 3.569 kasus, sedangkan ditahun 2014 meningkat menjadi 5.857 kasus. dari 5.857 kasus yang terjadi di wilayah Polda Banten, sebanyak 2.191 kasus dapat diselesaikan. Jumlah tersebut menurun dibanding 2013, dari 3.569 kasus yang terjadi, sebanyak 2.077 kasus yang dapat terselesaikan (Polda Banten, 2015)."”

Tidak ada seorangpun yang berada dibawah kalong langit ini hidupnya tanpa dosa. Paulus dalam suratnya kepada jemaat di Roma menyatakan bahwa "semua orang telah berbuat dosa dan telah kehilangan kemuliaan Allah" (Rm. 3:23), dan akibat dosa itu adalah maut (Rm. 6:23). Keberdosaan manusia dihadapan Allah membawa hidupnya jauh dari Allah dan berada dibawah hukuman, sehingga manusia memerlukan pertobatan untuk meninggalkan hidupnya yang lama dan percaya kepada Yesus Kristus yang

${ }^{1}$ Riny Handayani, “Analisis Dampak Kependudukan terhadap Tingkat Kriminalitas di Provinsi Banten," Jurnal Administrasi Publik 8, no. (2017).

214 | Jurnal Excelsis Deo: Jurnal Teologi, Misiologi dan Pendidikan 
telah mati karena dosa-dasa manusia dan bangkit pada hari yang ketiga, sehingga oleh iman, orang berdosa dapat dibenarkan dihadapan Allah. Menurut Guthrie, "Paulus mengerti keadaan manusia yang sudah berdosa, dan memahami bahwa manusia tidak dapat menyelamatkan dirinya sendiri, namun Allah telah menyediakan keselamatan bagi dia. Ajarannya tentang pembenaran berkenaan dengan cara Allah menyelamatkan orang berdosa, tetapi ia tak pernah menyarankan bahwa manusia sendiri tak punya andil di dalamnya. Karunia pembenaran dari Allah membutuhkan satu tanggapan saja, yakni menerimanya. Walaupun demikian, tanggapan yang penuh iman menyiratkan bahwa orang percaya meninggalkan segala sesuatu yang dapat disebut ketidak-benaran. Paulus mengajarkan dalam surat Roma 6:1 bahwa manusia tak dapat bertekun dalam dosa supaya semakin bertambah anugerah (kasih karunia), dan dengan demikian ia menunjukkan pandangannya bahwa seorang yang dibenarkan tidak bisa belum bertobat."

\section{Bagi Murray dan Torrance} "pertobatan adalah syarat mutlak untuk beroleh keselamatan. Yesus memulai pelayanan-Nya di muka umum dengan seruan 'bertobatlah', dan salah satu ucapan-Nya sebelum Ia naik ke Surga

${ }^{2}$ Donald Guthrie, Teologi Perjanjian Baru 2, Ke-4. (Jakarta: BPK Gunung Mulia, 1996), 234. ialah, 'pertobatan dan pengampunan dosa harus diberitakan kepada segala bangsa' (Luk. 24:47, bnd 13:3-5). Baik Petrus (Kis. 2:38) maupun Paulus (Kis. 17:30) memberitakan mutlak perlunya pertobatan, dan dalam Kis 20:21 Paulus meringkas injilnya dengan, 'bertobat kepada Allah dan percaya kepada Tuhan Yesus Kristus'. Tuntutan supaya bertobat, dan kenyataan bahwa pertobatan adalah mutlak perlu untuk pengampunan dosa dan beroleh hidup yang kekal, menyatakan bahwa keselamatan mustahil tanpa pertobatan. 'Iman' tanpa pertobatan bukanlah iman yang membawa kepada keselamatan."

Tujuan dari artikel ini adalah 1). Untuk mengetahui bagaimanakah studi bibiografi kehidupan Paulus? 2). Untuk mengetahui apakah pertobatan paulus dapat menjadi model pertobatan pelaku kriminalitas saat ini?

\section{METODE}

Metodologi dipakai dalam penelitian ini adalah metodologi kualitatif bibliografis yaitu dengan menggunakan "buku-buku referensi (reference books). Buku-buku referensi maksudnya ialah koleksi buku-buku yang memuat informasi spesifik dan paling umum serta paling sering dirujuk untuk keperluan cepat. Biasanya tidak untuk dibaca tamat secara keseluruhan,

${ }^{3}$ J.Murray dan J.B Torrance, "Tobat, Pertobatan," Ensiklopedi Alkitab Masa Kini, 2 Jilid (Jakarta: Yayasan Komunikasi Bina Kasih/OMF, 1996), 486. 
melainkan hanya untuk kebutuhan mencari jawaban tentang sesuatu secara singkat atau terfokus pada satu dua aitem tertentu saja."4 Buku-buku referensi tersebut adalah: "a. Kamus (kamus umum dan khusus menurut disiplin tertentu); b. ensiklopedi (umum dan khusus); c. buku indeks: indeks buku, artikel dari jurnal atau majalah berkala; d. buku bibliografi berisi informasi buku-buku bidang atau aspek tertentu." 5

\section{HASIL DAN PEMBAHASAN}

\section{Tempat Asal dan Keluarga Paulus}

Tempat asal Paulus tidak sulit dipastikan bahwa Paulus dilahirkan di kota Tarsis yang merupakan propendi Silisia dengan status sebagai warga negara Roma. Elis menyatakan bahwa walaupun ia dari suku Benyamin dan anggota Farisi yang aktif, ia lahir di kota Tarsis sebagai warga negara Roma (Kis. 16:37; 21:39; 22:25). ${ }^{6}$ Hal yang senada dikatakan oleh Herbert dimana Paulus dilahirkan di Tarsus merupakan daerah Sisilia sebagai pusat kebudayaan dan ilmu pengetahuan Yunani (Kis. 21:39). ${ }^{7}$ Dari sisi yang lain Drane menuturkan bahwa sesungguhnya Paulus tidak dilahirkan di Palestina. Sama seperti banyak orang bertobat

${ }^{4}$ Meztika Zed, Metode Penelitian Kepustakaan, Ke-3. (Jakarta: Yayasan Pustaka Obor Indonesia, 2014), 10.

${ }^{5}$ Ibid.,10

${ }^{6}$ Ellis. E.E, "Paulus," Ensiklopedi Alkitab Masa Kini, 2 Jilid (Jakarta: Yayasan Komunikasi Bina Kasih/OMF, 1996), 208.

${ }^{7}$ Haag Herbert, Kamus Alkitab (Flores: Nusa Inda, 1996), 324.

216 | Jurnal Excelsis Deo: Jurnal Teologi, Misiologi dan Pendidikan pada hari pentakosta, ia seorang Yahudi helenis. Ia berasal dari kota Tarsus di propensi Silisia, dan ia sebagai warga negara Roma. ${ }^{8}$

Berdasarkan argumentasi di atas maka tempat kelahiran Paulus bukan di daerah Palestina tetapi di Tarsis yang merupakan daerah Silisia dan sebagai warga negara Roma. Sehubungan dengan keluarga Paulus, orang tuanya adalah orang Yahudi sebagaimana yang dinyatakan Wahono di mana Orang tua Paulus adalah anggota kelompok Yahudi ortodoks yang mendidikan anaknya menurut ajaran Farisi yang keras (Kis. 23:6; 26:5; Flp. 3:5), dengan status kewarganegaraan Romawi, yang berarti memiliki kedudukan social yang cukup terhormat. Anak-anak mereka juga mempunyai kewarganegaraan Romawi karena hak sejak lahir (Kis. 22:25-29). ${ }^{9}$ Tenney juga menyatakan "Saulus atau yang lebih dikenal sebagai Paulus, dilahirkan dalam sebuah keluarga Ibrani yang berdisiplin keras menjelang abad yang pertama. Kota asalnya adalah Tarsus, sebuah kota metropolitan yang sibuk di Kilikia, yang terletak di pojok timur laut tengah. ${ }^{10}$

Wahono juga juga menyatakan bahwa keluarga Paulus dari kelompok Yahudi yang berdisiplin keras dengan

${ }^{8}$ John Drane, Memahami Perjanjian Baru (Jakarta: BPK Gunung Mulia, 1995), 289.

${ }^{9} \mathrm{~S}$. Wismondi Wahono, di Sini Kutemukan (Jakarta: BPK Gunung Mulia, 1987), 413

${ }^{10}$ Merril C. Tenney, Survey Perjanjian Baru, ke-3. (Malang Jawa Timur: Gandum Mas, 1993), 309. 
memegang ajaran hukum Taurat secara ketat yang diturunkan oleh nenek moyang mereka. Selain itu, keluarga Paulus termasuk keluarga yang kaya sebagaimana dikemukakan hak bahwa "Ia berasal dari keluarga Yahudi (Flp. 3:5) yang berbahasa Aram (Kis. 13:9) dan kaya (Kis. 22:28). ${ }^{11}$

Orang tua Paulus tidak melupakan ajaran yang telah diajarkan oleh nenek moyang mereka untuk menyunati anak laki-laki yang lahir ketika berumur delapan hari seperti yang dilakukan Abraham kepada anaknya Ishak (Kej. 21:1-7). Di mana sunat merupakan tanda perjanjian antara Allah dan Abraham serta keturunannya untuk menyatakan sebagai umat yang khusus di hadapan-Nya (Kej. 17:1-26). Haag mengutarakan mengenai penyunatan Paulus sebagai berikut, "Hari kedelapan setelah lahir ia disunati (Flp. 3:5) dan diberi nama Saul (nama Romawi: Paulus, Kis. 13:9)."12

Sangatlah jelas bahwa Paulus berasal dari keluarga Ibrani yang memiliki tingkat kedisiplinan yang keras. Oleh karena itu orang tua Paulus menerapakan disiplin yang ketat dalam mengajar.

\section{Pendidikan Paulus}

Paulus sebagai murid yang berprestasi dan berdisiplin dalam pendidikannya. Oleh karena itu, "Sewaktu masih mudah, orang tua

\footnotetext{
${ }^{11}$ Haag Herbert, Kamus Alkitab (Flores: Nusa Inda, 1989), 324.
}

${ }^{12}$ Ibid., 324.
Paulus memutuskan ia harus menjadi seorang rabi (guru hukum Taurat)."13

Kota Tarsus tempat kelahiran Paulus merupakan pusat Pendidikan dan kebudayaan saat itu sehigga dapat dipastikan Paulus mendapat pendidikan di kota tersebut semasa kecilnya. "sewaktu seorang anak kecil di Tarsus, ia belajar tentang tradisis-tradisi umat Yahudi mengenai pendidikan yang teratur di Sinagoge setempat. Alkitabnya pertama kemungkinan besar septuaginta, terjemahan Perjanjian Lama ke dalam Bahasa Yunani."14 Mengenai mekanisme pendidikan Paulus, sesungguhnya "Ia dididik secara ketat menurut adat istiadat Yahudi, mempelajari Bahasa Ibrani dan Kitab Suci, juga keahlian membuat tenda (Kis. 8:3). Ia sangat mahir berabahasa Aram yang mungkin digunakan di rumah, juga Bahasa Yunani, yang merupakan Bahasa umum di Tarsus. Mungkin ia juga mengenal sedikit Bahasa Latin meskipun tidak ada bukti mengenai pengeahuannya."15

Ketika masi kanak-kanak "Pada umur enam tahun, dia pergi ke sekolah untuk pertama kalinya. Segera ia dapat membaca, dia diberi gulungan-gulungan perkamen kecil yang bertuliskan bagian-bagian tertentu dari kitab Taurat dan itu harus dihafalkan. Bagian-

\footnotetext{
${ }^{13}$ John Drane, Memahami Perjanjian Baru Pengantar Historis-Teologis, ke-16. (Jakarta, 2016), 209.

${ }^{14}$ Ibid., 209.

${ }^{15}$ Merril C. Tenney, Survey Perjanjian Baru (Malang: Gandum Mas, 1995), 305.
} 
bagian itu adalah: (1) Shema (Bil. 6:4-9; 11:13-21; 15:37-41). Kata Ibrani Shema berarti 'Dengarlah' dan judul itu berasal dari Ulangan 6:4, "dengarlah hai orang Israel: Tuhan itu Allah kita, Tuhan itu Esa!" ayat itulah yang diapakai untuk memulai setiap kebaktian mereka dalam rumah ibadat.

(2) Hallel berarti "pujilah Allah!" semuanya dalah Mazmur puji-pujian dan hari paska. (3) Kisah penciptaan (Kej. 1-5). (4) hukum upacara (Im. $1: 8) .{ }^{16}$

Melalui pendidikan yang ketat, ia menjadi anak yang cerdas di mana "Ketika Paulus berumur dua belas tahun, dia menjadi apa yang disebut “Anak Hukum Taurat." Pada usia itu ayahnya tidak lagi bertanggung jawab apakah Paulus mentaati hukum agama atau tidak, melainkan Paulus sendiri harus bertanggung jawab hal itu. Pada hari sabat yang jatuhnya paling dekat dengan ulang tahunnya yang kedua belas atau tiga belas, dia dibawah ke rumah ibadat. Di situ dia dipanggil untuk tampil ke mimbar dan membaca salah satu dari pelajaran-pelajaran Taurat untuk hari itu. Kemudian dia diberi beberapa pertanyaan untuk diuji pengetahuannya, dan setelah dia dapat menjawab secara memuaskan, dia dianggap bukan kanak-kanak lagi melainkan sudah dewasa." ${ }^{17}$ Pada masa itu "Bagi kebanyakan anak-anak, selesailah pendidikan mereka pada tahap itu, tetapi tidak bagi Paulus. Dia

${ }^{16}$ William Barclay, Duta bagi Kristus (Jakarta: BPK Gunung Mulia, 1998), 10.

${ }^{17}$ Ibid., 11. harus menjadi rabi, yaitu semacam guru besar pada perguruan tinggi. Untuk itu dia harus belajar lagi dan menerima pendidikan yang lebih tinggi, yang jaman ini bisa disamakan dengan universitas. Di situ dia melanjutkan mempelajari Kitab Perjanjian Lama, sebab hanya buku itulah yang dimiliki orang Yahudi. Dia belajar untuk mencari arti-arti tersembunyi dalam Taurat yang tidak dapat dilihat oleh orang biasa." $" 18$

Prestasi yang ditempu Paulus nyata di mana "Paulus berbicara dengan dua bahasa, yaitu Bahasa Aram dan Bahasa Yunani. Disamping itu ia dapat membaca Kitab Suci Ibrani dengan lancar dan baik." 19 Tentunya prestasi yang dimiliki Paulus tidak lepas dari kedisiplinannya menggunakan waktu dengan baik untuk belajar di mana "cara belajar yang intensif itu berlangsung terus sampai Paulus mencapai umur dua puluh atau dua puluh satu tahun setelah itu dia memenuhi syarat untuk menjadi seorang Rabi dan guru." 20

Paulus sebagai calon rabi diharapkan memiliki satu keterampilan di mana "setelah Paulus menyelesaikan pelajaran-pelajarannya di sekolah tinggi itu, dia belajar tukang tenda. Dia tinggal di kota Tarsus di propensi Kilikia. Di daerah itu dipelihara kawanan-kawanan kambing yang mempunyai bulu khas. Bulu binatang itu dijadikan wol untuk membuat tenda,

\footnotetext{
${ }^{18}$ Ibid.,11.
${ }^{19}$ Wahono, Di Sini Kutemukan, 414.
${ }^{20}$ William Barclay, Duta bagi Kristus,

${ }^{18}$ Ibid.,11.
${ }^{19}$ Wahono, Di Sini Kutemukan, 414.
${ }^{20}$ William Barclay, Duta bagi Kristus,

${ }^{18}$ Ibid.,11.
${ }^{19}$ Wahono, Di Sini Kutemukan, 414.
${ }^{20}$ William Barclay, Duta bagi Kristus, 12.
}

218 | Jurnal Excelsis Deo: Jurnal Teologi, Misiologi dan Pendidikan 
kain korden serta macam khiasan gantung lainnya." 21 Keterampilan yang dibuat Paulus adalah hal yang biasa bagi seorang yang dipesiapkan untuk menjadi Rabi. Keterampilan yang dimiliki Paulus hanya merupakan salah satu dari sekian banyak keterampilan yang harus diketahui seorang Rabi. Sebab menjadi seorang rabi diharuskan untuk mengetahui sekurang-kurangnya satu keterampilan. Keharusan seorang Rabi untuk memiliki keterampilan merupakan ajaran Yahudi karena "mereka berpendapat bahwa seorang guru tidak boleh menerima uang dari murit-muritnya. Sala seorang arif di antara mereka mengatakan kepada semua guru, 'janganlah membuat murid-muridmu sebuah kampak untuk alat pencarian nafkamu; buatlah mereka makohtamu yang memberi kemuliaan kepadamu.' Orang-orang Yahudi juga berpendapat bahwa setiap orang, bahkan sarjana yang paling pandaipun, harus mempunyai suatu keterampilan. Ada pameo Yahudi yang berbunyi. Cintailah pekerjaan.' 'Orang yang tidak mengajarkan suatu keterampilan kepada anaknya, mengajar dia untuk merampok.' Sungguh bagus pengajaran Hukum Agama jika disertai suatu keterampilan duniawi sebab hal tersebut dapat menjauhkan orang dari perbuatan jahat; tetapi segala hukum agama yang tidak disertai pekerjaan, pastilah berakhir dengan kegagalan dan akan menyebabkan kehahatan. Sebab itu,

${ }^{21}$ Ibid., 13. dalam bacaan-bacaan, sering kali menemukan Rabi-rabi yang bekerja sebagai penggiling tepung, tukang sepatu, penjahit, tukang roti, tukang besi, dan pekerjaan-pekerjaan keahlian lainnya. ${ }^{22}$

\section{Sebelum Pertobatan Paulus}

Paulus sebagai anggota Sanhedrin sangat membenci orang Kristen karena pengakuan mereka Yesus sebagai Mesias. Oleh karena itu, ia berusaha untuk menghetikan pengajaran orang-orang Kristen yaitu dengan menganiaya dan menghukum mati setiap orang yang mengakui Yesus sebagai Mesias. Di mana Paulus "sebagai orang mudah (Kis. 7:58; Gal. 1:13 dab; 1 Kor. 15:9) Paulus mendapat kekuasaan resmi untuk mengatur penganiayaan orang Kristen, dan sebagai anggota sinagoge atau dewan Sanhedrin, aku juga setuju mereka dihukum mati (Kis. 26:10). ${ }^{23}$ Karena "sama seperti pemimpin lainnya, Paulus mencela "Mesias" yang disalibkan itu. Ia membenci kegiatan para pengikut Kristus gadungan itu. Sebab mereka menyatakan setelah penyaliban yang memaluhkan itu Ia telah bangkit dari kematian dan Allah mengakui-Nya sebagai Mesia dengan memberikan tempat sangat terhormat" (Kis. 2:22,

${ }^{22}$ Ibid., 13. Ensiklopedi Alkitab Masa Kini, 2 Jilid (Jakarta: Yayasan Komunikasi Bina Kasih/OMF, 1996), 208. 
24)". ${ }^{24}$ Menurut Warren "Ia dulu seorang penghujat sebab Ia telah menyangkal detuhanan Yesus Kristus dan memaksa orang lain untuk menyangkal Dia. Ia juga dulu seorang penganiaya yang tindakan kekerasan untuk membinasakan Jemaat Kristus. Mengancam dan membunuh muridmurid Tuhan sungguh merupakan kehidupan Paulus dulu (Kis. 9:1). Ia telah mengniaya Jemaat Kristus (1 Kor. 15:9)". ${ }^{25}$

Tampak jelas bahwa Paulus sangat membenci ajaran Kristen, dan ia sungguh-sungguh menolak kesaksian mereka tentang Kristus yang sudah bangkit itu. Ia beranggapan pengajaran Kristen adalah ajaran bidat yang menyesatkan. "Pada tahun-tahun setelah kebangkitan Yesus Kristus, ia mulai menganiaya orang-orang Kristen kerena ia mengira bahwa mereka menyesatkan orang daripada ibadat kepada Allah yang sejati."26 Sejalan dengan pikiran itu, Gering berkata tentang tindakan Paulus tersebut sebagai "seorang Farisi yang bersemangat dan melakukan penganiayaan terhadap umat Allah di Yerusalem." 27 Ambisi Paulus menghentikan ajaran orang Kristen identik dengan karakternya sebagai

${ }^{24}$ Drane, Memahami Perjanjian Baru Pengantar Historis-Teologis. 305.

${ }^{25}$ Warren W. Wiersbe, Setia di dalam Kristus (Bandung: Yayasan Kalam Hidup, 2004), 19.

${ }^{26}$ McElrath W.N. dan Billy Mathias, Ensiklopedi Alkitab Praktis (Bandung: Lembaga Literatur Baptis, 1989), 104.

${ }^{27}$ Gering M. Howard, Ensiklopedi Alkitb (Malang: Tanpa Penerbit, 1964), 258. "seorang yang ganas, seorang yang kasar, sombong dan kurang ajar."28

Stevanus yang penuh dengan

Roh Kudus memberikan kesaksian mengenai kebenaran Allah di dalam Yesus Kristus yang telah membangkitkan kemarahan para pemimpin Yahudi. Sebagai akibatnya Stevanus dilontar dengan batu hingga meninggal. Paulus menyaksikan peristiwa tersebut setuju sebab dianggapnya menghujat nama Allah yang suci. "Menurut jalan pemikiran Paulus, Stevanus adalah seorang penghujat nama Allah dan bersalah dihadapan hukum."29

Rupanya Paulus tidak puas menyaksikan kematian Stevanus dan mulai merencanakan mengadakan penganiayaan secara besar-besaran kepada orang-orang percaya yang mengakui Yesus sebagai Mesias. "Sementara itu berkobar-kobar hati Saulus untuk mengancam dan mebunuh murid-murid Tuhan. Ia menghadap imam besar dan meminta surat kuasa dari padanya untuk dibawah kepada mejelis-majelis Yahudi di Damsyik, supaya jika ia menemukan laki-laki atau perempuan yang mengikuti jalan Tuhan, ia menangkap mereka dan membawa mereka ke Yerusalem" (KIS. 9;1,2). Mengacu dari ayat tersebut, Drane menyatakan "Paulua seoran yang cerdik dan seorang Farisi yang berpengaruh. Sewaktu ia melihat orang Kristen keluar dari Yerusalem, ke kota

\footnotetext{
${ }^{28}$ Wiersbe, Setia di dalam Kristus., 18.

${ }^{29}$ Merril C. Tenney, Survey Perjanjian
} Baru. 306.

220 | Jurnal Excelsis Deo: Jurnal Teologi, Misiologi dan Pendidikan 
lain, Paulus menyadari bahwa tindakan penganiayaan terhadap Stevanus dan orang lain, tidak menyelesaikan masahnya sebaliknya justru menyebabkan agama Kristen ke wilayah-wilayah lain kekaisaran Roma." ${ }^{30}$ Selanjudnya Drane berkata Bahwa "Paulus ingat orang-orang Roma pernah memberikan hak kepada Iman Besar untuk memintah agar penjahatpenjahat Yahudi dari bagian lain kekaisaran Roma dieksekusi (1 Makabe 15:15-24). Jadi ia pergi kepada Imam Besar untuk meminta surat yang memberikan kuasa guna mengejar orang-orang Kristen sampai ke Damsyik dan membawa Kembali ke Yerusalem untuk diadili dan dihukum." $" 31$

Dapat disimpulkan bahwa Paulus sebagai Rabi Yahudi sangat membenci pengajaran orang Kristen dan menganggap mereka sedang menghujat nama Allah karena mereka menyatakan bahwa Yesus Kristus adalah Mesias yang telah mati dan bangkit Kembali serta menjadi penyelamat manusia.

\section{Pertobataan Paulus}

Paulus sebagai Rabi Yahudi dengan gigi menentang pengajaran pengikut-pengikut Kristus. Tindakan Paulus untuk menghentikan tersebar luasnya pengajaran mereka, ia

${ }^{30}$ Drane, Memahami Perjanjian Baru Pengantar Historis-Teologis. 306.

${ }^{31}$ Ibid., 306 memintah surat kuasa kepada Imam Besar dengan maksud untuk menangkap serta menghukum setiap orang yang mengakui Yesus sebagai Mesias. Tetapi ketika Paulus menerima surat kuasa dari imam besar, tiba-tiba terjadi sesuatu dalam dirinya saat perjalanannya ke Damsyik yang mengakibatkan pertobatannya. Mengenai peristiwa tersebut Free menuturkan "Saulus berangkat dari Damsyik, dengan rencana untuk mencari orang Kristen yang dapat dibawa tertawan ke Yerusalem (Kis. 9:1-12). Sementara ia mengadakan perjalanan menuju ke Damsyik, tibatiba suatu cahaya mengelilingi dia; ia rebah ke tanah dan mendengar suara yang berseruh kepadanya, "Saulus, Saulus mengapakah engkau menganiaya Aku?" Saulus bertanya, siapakah Engkau Tuhan?" (Kis 9:4-5). Saulus bertanya apa yang harus ia lakukan dan Tuhan menyuruh dia pergi ke Damsyik ke rumah Yudas di jalan lurus. Di sana ia tinggal selama tiga hari dan kemudian ia bertemu dengan seorang yang Bernama Ananias, yang meletakkan tangan ke atasnya dan segera selaput kebutaan gugur dari matanya." 32 Tenney juga memberikan argumentasinya sehubungan dengan pertobatan Paulus sebagai berikut, "Lukas mencatat bahwa peristiwa itu terjadi di suatu tempat di dekat

${ }^{32}$ Joseph P. Free, Arkeologi dan Sejarah Alkitab, ke-1. (Malang: Malang Gandum Mas, 1997), 403.

Jurnal Excelsis Deo: Jurnal Teologi, Misiologi dan Pendidikan | 221 
Damsyik (Kis. 9:3); bahwa ada suatu cahaya terang benderang (9:3); ada suatu suara yang berkata-kata kepada Paulus dan dapat didengar oleh temanteman seperjalanannya (9:7), meskipun mereka tidak mengerti apa yang dikatakan itu (22:9).

Berdasarkan penjelasan Free dan Tenney tidak dapat diragukan lagi mengenai pertobatan Paulus terjadi "pada perjalan menuju ke Damsyik untuk menangkap orang-orang Kristen, ia berjumpa dengan Kristus melalui suatu penglihatan." ${ }^{33}$ Gering juga memberikan steitmennya tentang perjumpaan Paulus dengan Yesus sebagai berikut, "Paulus (Ibrani=Saul) seorang Yahudi selaku orang mudah, mengganggu orang-orang Kristen zaman dulu akan tetapi menjadi pengikut Kristus setelah penglihatannya yang dialami dalam perjalanan menuju ke Damsyik." 34

$$
\text { Paulus sebenarnya patut }
$$

mendapat hukuman dari Allah sebab kejahatan yang telah dibuatnya yaitu menganiaya orang-orang percaya. Tetapi karena kasih Allah yang begitu besar, Ia telah memanggil Paulus untuk dijadikan alat-Nya. "Allah yang mengasihinya tidak membalas kepada Paulus apa yang layak diterimanya. Sebaliknya, Allah yang penuh kasih karunia membalas kepada Paulus apa yang tidak layak diterimanya, untuk menyatakan kasih-Nya, maka Allah melimpahkan kasih karunia-Nya dan

\footnotetext{
104.

${ }^{33}$ Mathias, Ensiklopedi Alkitab Praktis

${ }^{34}$ Howard, Ensiklopedi Alkitb, 378.
}

mengasihi orang berdosa."35 Warren juga mengemukakan bahwa "kasih karunia Allah telah mengubah seorang penganiaya menjadi pemberita injil, dan seorang pembunuh menjadi gembala siding dan utusan injil. Sungguh drastis perobahan dalam kehidupan Paulus sehingga jemaat di Yerusalem mencurigai, jangan-jangan perubahan itu hanya suatu tipu muslihat saja, dan mereka sukar sekali menerima." 36

Pengalaman Paulus yang spektakuler ketika ia bertobat dalam perjalanan menuju ke Damsyik, telah merubah kehidupannya secara drastis. "Pertobatan Paulus atau peralihannya dari agama Yahudi ke agama Kristiani, bagi Paulus sendiri bukan suatu evolusi atau perkembangan yang biasa. Dalam Galatia 1:13-14 dan Flp. 3:6 penganiayaan jemaat dihubungkan dengan kerajinannya sebagai orang Yahudi. Tetapi dalam Flp. 3:7 dengan tegas ia berkata bahwa "apa yang dahulu merupakan keuntungan bagiku sekarang kuanggap rugi karena Kristus," ay. 8 oleh karena Dialah aku melepaskan semua itu dan kuanggap sampa."37

Pertobatan Paulus terjadi didasarkan pada inisiatif Allah dan sama sekali tidak didasari respon yang positif Paulus kepada Allah untuk mencari kebenaran. "Pertobatan Paulus adalah suatu peristiwa dalam hidupnya

\footnotetext{
${ }^{35}$ Wiersbe, Setia Di Dalam Kristus 19. ${ }^{36}$ Ibid., 21.

${ }^{37}$ Tom Jacobs, Paulus Hidup, Karya
} dan Teologinya (Jakarta: BPK Gunung Mulia, 1992), 51.

222 | Jurnal Excelsis Deo: Jurnal Teologi, Misiologi dan Pendidikan 
yang betul-betul merupakan tindakan Allah."38 Disisi lain, "Paulus sendiri menyatakan bahwa ia bertobat karena digerakan oleh sebuah wahyu khusus dari Kristus (1 Kor. 15:8; Gal. 1:15-16; bdk 9:1). ${ }^{39}$

Panggilan Allah kepada Paulus dimaksudkan untuk membawa kabar baik kepada bangsa-bangsa kafir mengenai jalam kebenaran di dalam Yesus Kristus. Dalam penuturan Haag nyata bahwa, "Di dalam wahyu khusus itu Paulus sekaligus dipanggil menjadi rasul orang kafir." 40 Pernyataan ini sama dalam argumentasi yang deikemukakan Warren yang mana "Tugas Paulus ialah mengabarkan injil kepada orang-orang bukan Yahudi (Kis. 9:15 dan Ef. 3:1-12), tetapi ia selalu memulai pelayanannya diantara diantara orang Yahudi." ${ }^{\text {41 }}$ Dari satu segi Getz berkata, "Sesudah pertobatannya hanya ada satu tujuannya: Melaksanakan kehendak Allah. Dan melalui hubungan ini Paulus menjadi bebas untuk menjadi apa yang dikehendaki Allah bagi dia." ${ }^{42}$

\section{Paulus Model Pertobatan Pelaku Kriminalitas Saat Ini}

Tindakan Paulus menganiaya jemaat Tuhan di lihatnya sebagai suatu

\footnotetext{
${ }^{38}$ Ibid., 55.

${ }^{39}$ Haag Herbert, Kamus Alkitab 325.

${ }^{40}$ Ibid., 325.

${ }^{41}$ Wiersbe, Setia di dalam Kristus 196.

${ }^{42} \mathrm{Getz}$ A. Gene, Hiduplah dalam
} Kekudusan (Jakarta: BPK Gunung Mulia, 1993), 9. kejahatan terbesar dalam hidupnya. Perjumpaannya dengan Yesus dalam perjalan di Damsik telah merobah hidupnya secara seratus persen. Paulus mngakui bahwa ia adalah orang yang paling berdosa karena telah menganiaya Jemaan Allah, dan menjadikan dirinya contoh bagi orang yang akan percaya kepada Yesus Kristus (1 Tim. 1:13-16)

Memperhatikan pengalaman Paulus, melalui anugerah Allah, sebesar apapun tingkat kriminalitas yang diperbuat seseorang tidak akan membatasi ia untuk menerima anugerah dari Allah. Pengorbanan Kristus di kayu salib merupakan wujudnyata kasih Allah yang sempurna kepada manusia yang berdosa. Paulus dalam suratnya kepada jemaat Roma menyatakan bahwa "akan Allah telah menunjukkan kasihnya kepada oleh karena Kristus telah mati untuk ketika masih berdosa" (Rm. 5:8). Selanjudnya kepada jemaat Korentus, Paulus berkata "sebab yang sangat penting telah kusampaikan kepadamu. yaitu apa yang telah kuterima sendiri, ialah bahwa Kristus telah mati karena dosa-dosa, sesuai dengan Kitab Suci, bahwa Ia telah dikuburkan, dan bahwa Ia telah dibangkitkan, pada hari yang ketiga, sesuai denga Kitab Suci” (Kor. 15:3-4). Dalam Roma 10:9-10, Paulus menyatakan "sebab jika kamu mengaku dengan mulutmu, bahwa Yesus adalah Tuhan, dan percaya dalam hatimu, bahwa Allah telah membangkitkan Dia dari antara orang mati, maka kamu akan 
diselamatkan. Karena dengan hati orang percaya dan dibenarkan, dan dengan mulut orang mengaku dan diselatkan. Karena dengan hati orang percaya dan dibenarkan, dan dengan mulut orang mengaku dan diselamatkan."

Jadi pada prinsipnya, siapapun pelaku kriminalitas, sebesar apapun tingkat kejahatannya ketika ia sadar, bertobat dan peracaya kepada Yesus Kristus maka memperoleh pengampunan dosa dan keselamatan dari Allah.

\section{KESIMPULAN}

Tempat kelahiran Paulus bukan di daerah Palestina tetapi di Tarsis yang merupakan daerah Silisia dan sebagai warga negara Roma. Orang tua Paulus adalah anggota kelompok Yahudi ortodoks yang mendidikan anaknya menurut ajaran Farisi yang keras (Kis. 23:6; 26:5; Flp 3:5), dengan status kewarganegaraan Romawi, yang berarti memiliki kedudukan social yang cukup terhormat. Kota Tarsus tempat kelahiran Paulus merupakan pusat Pendidikan dan kebudayaan saat itu sehigga dapat dipastikan Paulus mendapat pendidikan di kota tersebut semasa kecilnya. "sewaktu seorang anak kecil di Tarsus, ia belajar tentang tradisis-tradisi umat Yahudi mengenai pendidikan yang teratur di Sinagoge. Prestasi yang ditempu Paulus nyata di mana "Paulus berbicara dengan dua bahasa, yaitu Bahasa Aram dan Bahasa Yunani. Disamping itu ia dapat membaca Kitab Suci Ibrani dengan lancar dan baik. Paulus sebagai anggota Sanhedrin sangat membenci orang Kristen karena pengakuan mereka Yesus sebagai Mesias. Oleh karena itu, ia berusaha untuk menghetikan pengajaran orang-orang Kristen yaitu dengan menganiaya dan menghukum mati setiap orang yang mengakui Yesus sebagai Mesias. pertobatan Paulus terjadi "pada perjalan menuju ke Damsyik untuk menangkap orang-orang Kristen, ia berjumpa dengan Kristus melalui suatu penglihatan.

Memperhatikan pengalaman Paulus, melalui anugerah Allah, sebesar apapun tingkat kriminalitas yang diperbuat seseorang tidak akan membatasi ia untuk menerima anugerah dari Allah. Pengorbanan Kristus di kayu salib merupakan wujudnyata kasih Allah yang sempurna kepada manusia yang berdosa. pelaku kriminalitas, sebesar apapun tingkat kejahatannya ketika ia sadar, bertobat dan peracaya kepada Yesus Kristus maka memperoleh pengampunan dosa dan keselamatan dari Allah. Melalui pengalaman pertobatan Paulus memberikan contoh pada pelaku kriminalitas bahwa tidak ada dosa yang tidak bisa diampuni apabila mereka sungguh-sungguh bertobat dan percaya kepada Yesus Kristus.

\section{KEPUSTAKAAN (REFERENCES)}

Donald Guthrie. Teologi Perjanjian Baru 2. Ke-4. Jakarta: BPK Gunung Mulia, 1996.

Drane, John. Memahami Perjanjian 224 | Jurnal Excelsis Deo: Jurnal Teologi, Misiologi dan Pendidikan 
Baru Pengantar Historis-Teologis. Ke-16. Jakarta, 2016.

E.E, Ellis. "Paulus." Ensiklopedi Alkitab Masa Kini, 2 Jilid. Jakarta: Yayasan Komunikasi Bina Kasih/OMF, 1996.

Free, Joseph P. Arkeologi dan Sejarah Alkitab. Ke-1. Malang: Malang Gandum Mas, 1997.

Gene, Getz A. Hiduplah dalam Kekudusan. Jakarta: BPK Gunung Mulia, 1993.

Haag Herbert. Kamus Alkitab. Flores: Nusa Inda, 1989.

Handayani, Riny. "Analisis Dampak Kependudukan terhadap Tingkat Kriminalitas di Provinsi Banten." Jurnal Administrasi Publik Vol 8, No. (2017).

Howard, Gering M. Ensiklopedi Alkitb. Malang: Tanpa Penerbit, 1964.

Jacobs, Tom. Paulus Hidup, Karya dan Teologinya. Jakarta: BPK Gunung Mulia, 1992.

Mathias, McElrath W.N. dan Billy.
Ensiklopedi Alkitab Praktis. Bandung: Lembaga Literatur Baptis, 1989.

Merril C. Tenney. Survey Perjanjian Baru. Ke-3. Malang Jawa Timur: Gandum Mas, 1993.

- Survey Perjanjian Baru. Malang: Gandum Mas, 1995.

Torrance, J.Murray dan J.B. "Tobat, Pertobatan." Ensiklopedi Alkitab Masa Kini, 2 Jilid. Jakarta: Yayasan Komunikasi Bina Kasih/OMF, 1996.

Wahono, S. Wismondi. di Sini Kutemukan. Jakarta: BPK Gunung Mulia, 1987.

Wiersbe, Warren W. Setia di dalam Kristus. Bandung: Yayasan Kalam Hidup, n.d.

William Barclay. Duta bagi Kristus. Jakarta: BPK Gunung Mulia, 1998.

Zed, Meztika. Metode Penelitian Kepustakaan. Ke-3. Jakarta: Yayasan Pustaka Obor Indonesia, 2014. 